\title{
口腔小唾液腺原発の上皮筋上皮癌例
}

\author{
延藤 洋子(1)・綾田 展明2) ・ 上上 登史 ${ }^{1)}$ \\ 宮口 衛3) ・西崎 和則1)
}

\section{Epithelial-Myoepithelial Carcinoma of the Oral Cavity Minor Salivary Gland}

\author{
Yoko Nobuto, Takashi Kawakami and Kazunori Nishizaki \\ (Okayama University) \\ Nobuaki Ayada \\ (Kagawa Prefectural Central Hospital) \\ Mamoru Miyaguchi \\ (Osaka University)
}

An epithelial-myoepithelial carcinoma arising from the oral cavity minor salivary gland in a 81year-old man is reported. The patient suffered from a large tumor with ulceration of the soft palate, however, his swallowing and speech were not disturbed.

The tumor showed characteristic histological features, such as double-layered tubular structures composed of inner ductal cells and outer clear cells. Inner ductal cells were positive for epithelial membrane antigen. Outer clear cells had rich glycogen and were positive for S-100 protein. The inner and outer cells differentiated into epithelial and myoepithelial cells, respectively.

The tumor is considered biologically to be a low grade malignancy because of its pattern of local infiltration growth and low rate of recurrence and metastasis. In this case, metastases to a cervical lymph node and the liver were detected. Although no treatment for the primary lesion has been performed, the patient is still alive at home one year after the diagnosis.

Key words : epithelial-myoepithelial carcinoma, minor salivary gland, soft palate, metastasis

\section{はじめに}

唾液腺の充実性腫瘍は，しばしば稀な病理組織像を呈 し，診断に難啮することがある.上皮筋上皮癌 epithelialmyoepithelial carcinoma (以下 EMC と略す) は唾液腺 に発生する稀な悪性腫瘍であり，1991年に改定された WHO 分類に，新しく採用された1)。従来は明細胞を主 体とする唾液腺腫瘍として，種々の名称で報告されてい たと考えられる腫瘍である．1972年の WHO 分類では, clear cell monomorphic adenoma として図説されていた が，1991年改定版ではこの図説が削除され，EMC とし て独立している。これは，稀な腫瘍であるが悪性である ことが認識されてきたからである21.

今回我々が経験した小唾夜腺原発の EMC を報告する と共に, 主に病理組織学的見地からの考察を加えて報告 する。

1）岡山大学医学部耳鼻咽喉科学教室

2) 香川県立中央病院耳鼻咽喉科

3) 大阪大学医学部耳鼻咽喉科学教室 


\section{症例}

患者：81歳, 男性.

主訴：口腔内腫瘤.

家族歴：父，弟が肺癌にて死亡.

既往歴：白内障, 前立腺肥大症.

現病歴 : 平成 5 年夏頃, 口内に水疱様のものを自覚し た。その後徐々に増大してきたため，平成 6 年 9 月 16 日， 香川県立中央病院耳鼻咽喉科を受診した。

現症: 初診時, 右軟口蓋に約 $8 \times 4 \mathrm{~cm}$, 一部潰瘍を伴 った弾性軟, 境界比較的明瞭な粘膜下隆起性腫瘍を認め た（図 1)，前方は硬口蓋に接し，内側は皃ぼ正中，後方 は口蓋舌弓に及んでいた。構音障害, 嚥下障害等は認め られず, 右頸部に $3 \times 3 \mathrm{~cm}$ の上内深頸りンパ節を触知 した.

血液生化学検査：著変なし.

単純頭部 CT : 右軟口蓋に主在する腫瘍陰影が認めら れた(図 2 ).

MRI : $\mathrm{T}_{1}$ 強調像にて, 辺縁整, 腫瘍断面は $3 \times 4 \mathrm{~cm}$

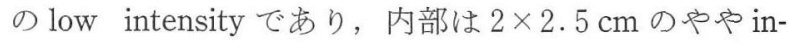
tensity の異なる部位が混在した腫瘍が認められた， $\mathrm{T}_{2}$ 強調像では high intensityとして認められ, 内部はより intensity が增していた(図 3 ).

経過：臨床像抒よび画像所見より内部に壊死を伴ら悪 性腫瘍を疑い, 生検を施行した。

病理組織所見：大小の胞巣を形成する小型異型細胞の 密な増殖を示し, 胞宩内に 2 層性配列を示す小管腔形成

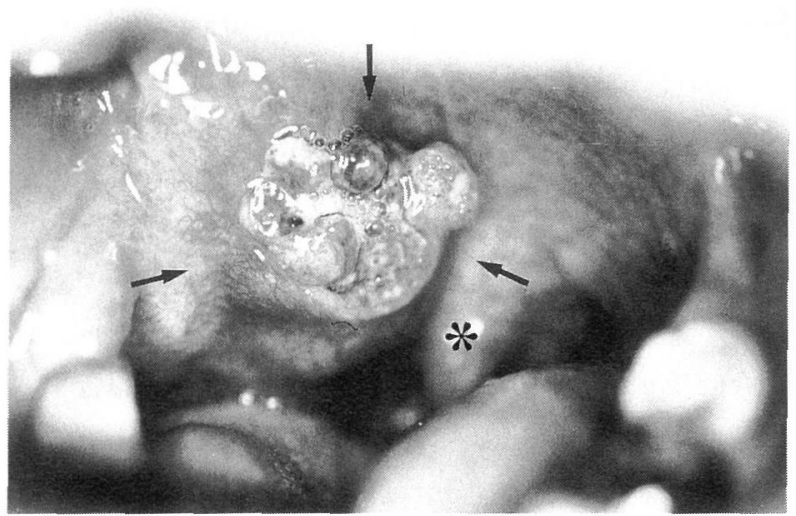

図 1 局所所見

右軟口蓋に隆起性腫瘍を認める。一部，潰瘍形成を伴っ ていた.

* : 口蓋垂 矢印：腫瘍

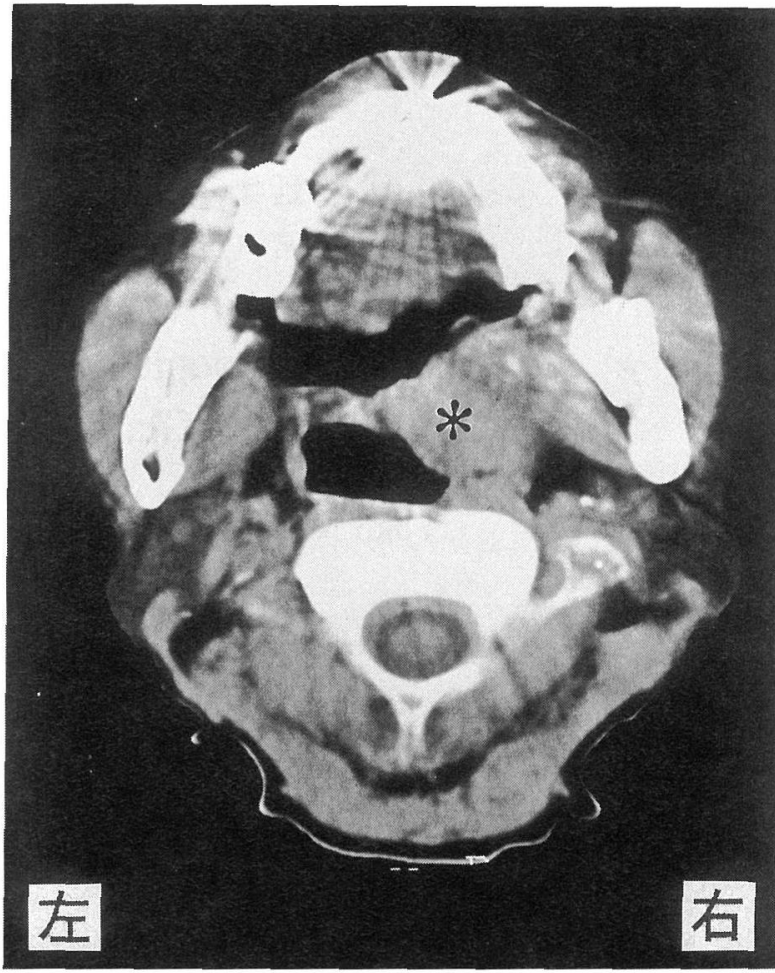

図 2 単純頭部 $\mathrm{CT}$ 右軟口蓋に腫瘍陰影を認める。 * : 腫瘍

も混在していた。核クロマチンは増加しているが，核分 裂像は殆どないことより，基底細胞腺腫と診断された。

しかし，右頸部リンパ節の硬さ，可動性の乏しさより 悪性の疑いが残り，平成 6 年10月12日右頸部リンパ節摘 出術を施行した。

リンパ節病理組織所見：内側に好酸性で立方状の小管 腔を形成する細胞と，外側にとれを取り团さ淡明な細胞 が増殖している 2 層性の構造が認められ，腫瘍間には硝 子化間質が介在していた(図 4).

免疫特殊染色：導管を形成している内側の細胞は抗 epithelial membrane antigen (EMA) 抗体に陽性で, 外 側の小細胞は，抗 S-100 protein 抗体で陽性であった。

ジアスターゼ消化 PAS 反応：外側の小細胞にグリ コーゲンの存在が著明であった(図 5 ).

以上より，リンパ節組織は EMC と診断された。口腔 内腫瘍の生検組織標本を再度検討したところ，細胞の淡 明化がリンパ節ほど顕著ではないが同様の腫瘍細胞を認 めたため，EMC と診断された。 


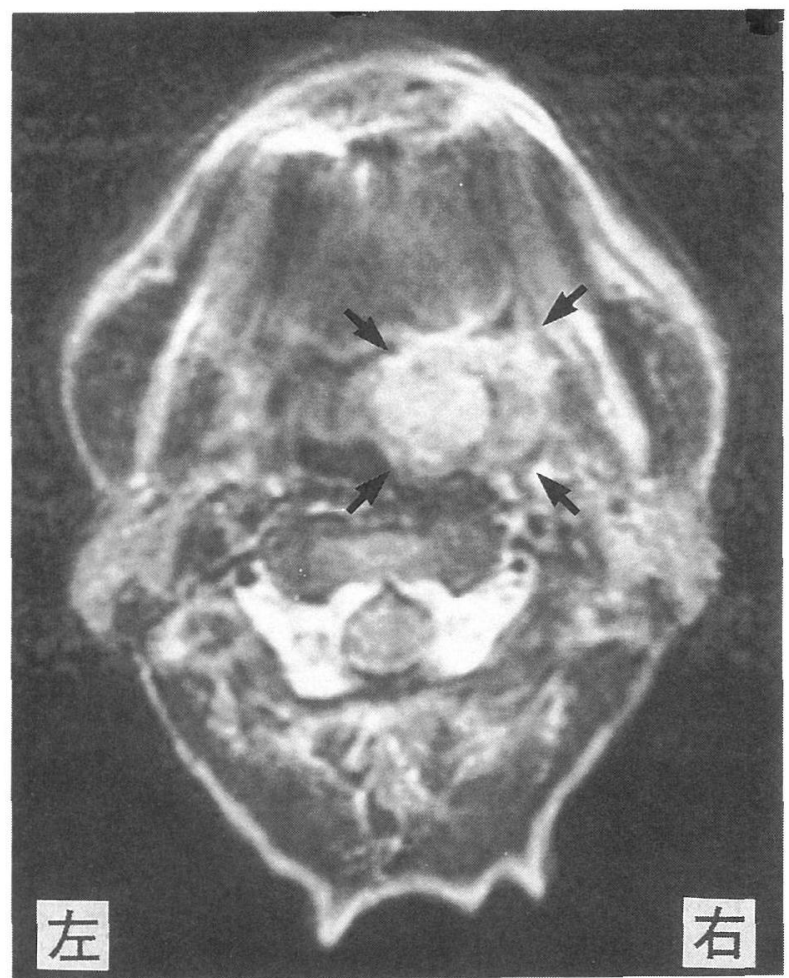

図 3 MRI ( $\mathrm{T}_{2}$ 強調像 $)$

内部にややintensity の増強している部の混在する腫瘍 を認める。

矢印：腫瘍

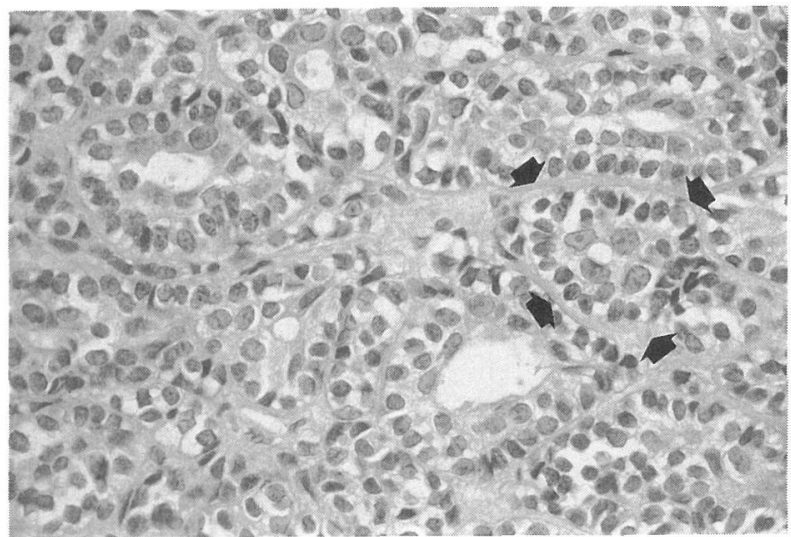

図 4 リンパ節病理組織所見 $(\mathrm{HE}$ 染色, $\times 400)$

内側に管腔を形成する立方状細胞と，外側に増殖した淡 明な細胞の 2 層性構造が認められる。

全身検索を行ったところ，腹部ェコーにて肝蔵に cluster sign陽性の腫瘤が認められ，単純 CT で，肝 S
2, 3 領域を中心に, $4 \times 5 \mathrm{~cm}$ の内部不均一な低吸収域を 認めた。造影 CT では，周辺がやや造影され，中心部は 造影されない壊死と思われる低吸收域があり，肝転移と 診断された。腎臓には異常所見は認められなかった。

肝臓に比較的大きな転移が認められたこと, 拱食障害 など，日常生活に支障をきたす症状が全くないこと，家 族の希望扣よび高齢であることを考慮して，治療は行わ ず経過を観察している。1 年を経過した現在, 腫瘍は徐 徐増大し，骨転移も認められるが，外来通院可能であ る.

\section{考察}

EMC は，1991年の WHO 分類の改定により，新しく 分類された唾液腺腫瘍である。しかし，EMCが新しく 発見された腫瘍といら訳ではなく, 1972年の WHO 分 類では, clear cell monomorphic adenoma の図説があっ たが，臨床組織学的に悪性であることが判明し，EMC と分類されたものである2).

Chen ${ }^{3)}$ は唾液腺原発の明細胞癌の症例を報告し, 過去 の報告から唾液腺の明細胞腫瘍は低悪性度の carcinoma と判断すべきであり, bimorphic variant と monomorphic variant に分類した。 以後の報告では, 明細胞 腫瘍4) 7), 明細胞癌8)9), glycogen-rich clear cell carcinoma ${ }^{10)} ， \mathrm{EMC}^{11) \sim 13)}$ と多様な名称で報告されてきた。 1991年 WHO 分類の改定 ${ }^{1)}$ では, epithelial-myoepithelial carcinoma と分類され，腺管を形成する内側の細胞と外 側の明細胞の 2 種類の細胞からなると定義された。

Batsakis $5^{2)}$ は, この改定に解説を加光，管腔を形成 する細胞は，介在部導管の所見を有し，外側の明細胞は 筋上皮でグリコーゲンと myofilamentを有し，S-100 亿 陽性であるとした。更に EMCを1) 明細胞優位，2）紡 錘型筋上皮型， 3 ) 導管上皮優位の 3 種類に分類した。 本症例は，口腔内原発巣では，3 ) の導管上皮優位型で あり，頸部リンパ節は 1 ) の明細胞優位型であった。

しかし，腫瘍細胞の中には，導管上皮様細胞之筋上皮 様細胞との両者の形態的特徴を合わせもった移行型細胞 も認められたと報告するもの4)58)122や，1つの腫瘍の中 に bimorphic variant $と$ monomorphic variant を示寸部 分が混在していたとするもの6)12)，また 2 層性の増殖像 を示寸腫瘍が再発時, 単層性に変化した症例を記載して いるもの1114)などの報告が認められる。これらの報告 は腫瘍細胞が，導管上皮，筋上皮の両方向に分化する能 

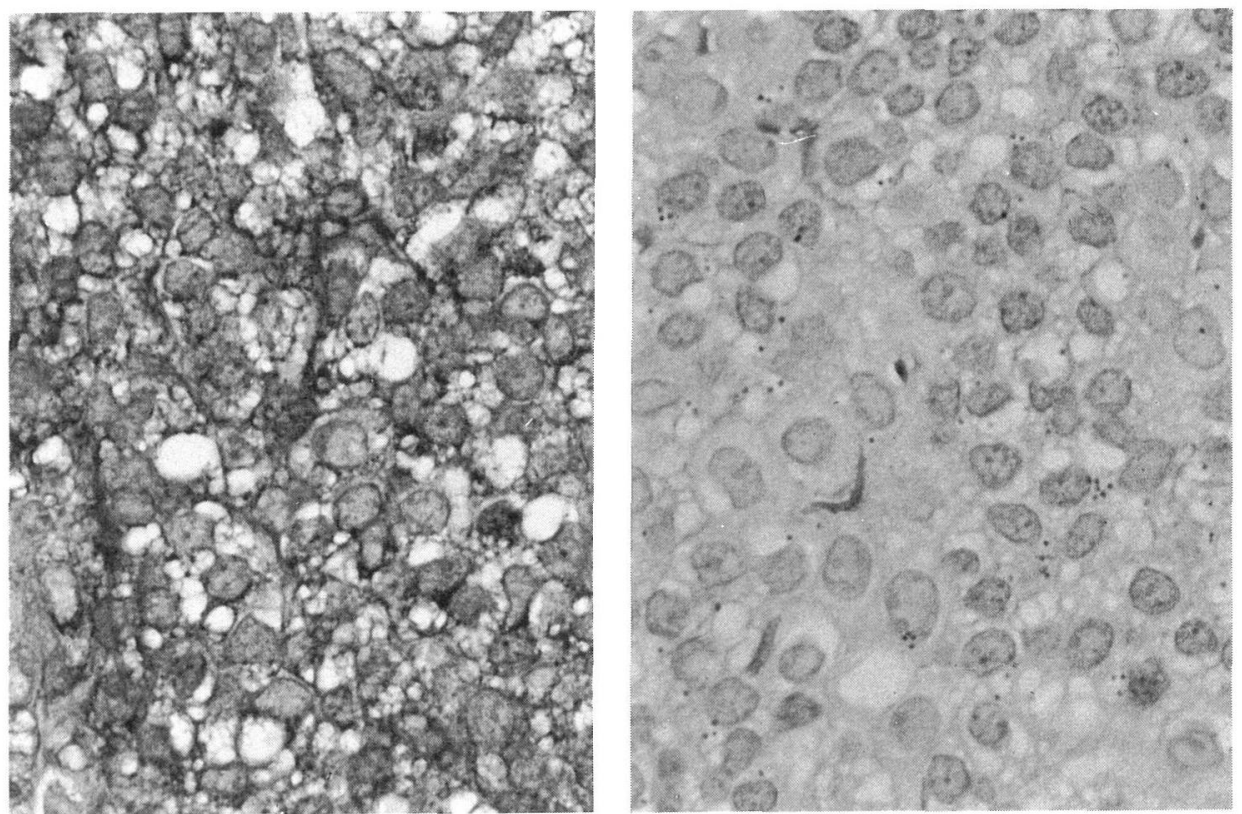

図 5 リンパ節組織ジアスターゼ消化 PAS 反応(左: PAS 染色, 右 : ジアスターゼ処理後, $\times 400)$.

PAS 染色で强陽性に染色される顆粒はジアスターゼ処理にて消失し，この顆粒はグリ コーゲンであると診断できる.

表 1 本邦に扣ける $\mathrm{EMC}$ 関連腫瘍報告例

\begin{tabular}{|c|c|c|c|c|c|c|c|c|}
\hline 報 告 者 & 年齢・珄 & 診 断 名 & 部位 & 先行期間 & 転移 & 再発 & 治療 & 術後経過期間 \\
\hline 林ら ${ }^{4)} \quad(1984)$ & 65 男 & 明細胞腫瘍 & 耳下腺 & 3 年 & - & + & 手術 & 6 年 \\
\hline 林ら（1984） & 73 男 & 明細胞腫瘍 & 耳下腺 & & - & - & 手術 & 1 年半 \\
\hline 林ら （1984） & 79 女 & 明細胞腫瘍 & 耳下腺 & 3 年半 & - & + & 手術 & $3 \sim 4$ 年 \\
\hline (1984) & 20 女 & 明細胞腫瘍 & 顎下腺 & & - & - & 手術 & 5 年 \\
\hline (1984) & 60 男 & 明細胞腫瘍 & 顎下腺 & & & & & 死亡※ \\
\hline 林ら （1984） & 76 男 & 明細胞腫瘍 & 耳下腺 & & \pm & - & 手術 & 死亡 \\
\hline (1984) & 25 女 & 明細胞腫瘍 & 硬口蓋 & & - & - & 手術 & 1 年半 \\
\hline (1984) & 77 女 & 明細胞腫痬 & 顎下腺 & & - & - & & 死亡※ \\
\hline 桜井ら 5 (1990) & 74 女 & 明細胞腫 & 口腔底 & 2 力月 & - & - & 手術 & 2 年半 \\
\hline 森川ら ${ }^{12)}(1990)$ & 54 男 & EMC & 耳下腺 & 5 年 & - & - & 手術 & \\
\hline 川上ら ${ }^{10)}(1990)$ & 35 女 & $\begin{array}{l}\text { glyogen-rich } \\
\text { clear cell carcinoma }\end{array}$ & 軟口蓋 & 3 年 & - & - & 手術 & 1 年半 \\
\hline 山岸ら ${ }^{16)}(1992)$ & 78 女 & 明細胞腺腫 & 口蓋 & 3 力月 & - & - & 手術 & 2 年 4 力月 \\
\hline 下田ら9（1992） & 62 男 & 明細胞癌 & 頓粘膜 & 5 年 & - & + & 手術 & \\
\hline 井野ら (1993) & 65 男 & 明細胞腫瘍 & 舌根部 & 6 力月 & - & - & 手術 & 1 年 \\
\hline 福島ら 13) (1994) & 71 女 & EMC & 硬口蓋 & 3 力月 & - & - & 手術 & \\
\hline 自験例 （1996） & 81 男 & EMC & 軟口蓋 & 1 年 & + & & 放置 & 1 年 \\
\hline
\end{tabular}

注）※: 本疾患に起因するものかどらか明らかでないことを示す。 空欄は不明. 
力のある未分化な細胞由来であることを示唆し，退形成 が進むにつれて，2 層性配列が失われていく可能性が考 えられる。

本腫瘍は組織学的に, 今回の症例で得た生検の結果の ように, 細胞異型や核分裂像が少ないこと, 高い分化傾 向を示すことより良性に判断されがちであり，初期には WHO 分類でも adenoma と分類されている. しかし， 局所的に浸潤性発育を呈し，発育は緩徐ではあるが，転 移, 再発も認められることょり, 生物学的に低悪性群に 分類されるよらになった。 しかし摘出術後 3 年で急速に 脳，肺転移を来し死亡した小児症例11) や，死亡率が 40 \%との報告15) もあり，悪性度に関しては注意が必要で ある。

今回の症例では, 原発巣の生検組織において, 細胞の 淡明化が顕著でなく，管腔形成部に 2 層性パターンが認 められたものの, 細胞異型や核分裂像が少なく, carcinoma とは診断されなかった。しかし，転移部の頸部 リンパ節に扣いて，淡明な腫瘍細胞が著明であり， $\mathrm{EMC}$ に特徵的な 2 層性構造が認められ，外側細胞のグ リコーゲンの存在, 腫瘍間の硝子化間質の存在といら, 他の睡液腺腫瘍ではみられない $\mathrm{EMC}$ に特徴的な所見が 認められたことより，最終的に EMC と診断された．肝 ・骨転移を来したが発育は緩徐であり, 診断後も 1 年担癌 状態を保っており，低悪性度と判断される.

EMC を疫学的に検索してみると，40歳代以上に好発 し，女性に多く認められる。大唾液腺に多く発生はする が，他の喠液腺腫瘍に比べ，小唾液腺からの発生率も高 い. 遠隔転移は $10 \%$ 程度認められ，局所再発については 40\%との報告4)15) むあるが，広範切除にて，多くは良好 な経過を示している5)810116)。治療に関しては，切除のみ 施行されることが多く, 切除後, 放射線療法を追加して いるもの ${ }^{11)}$ もあるが，手術のみで経過良好のため，そ の効果は不明である. 近年の本邦に括ける報告例を表 145)779)10012121316) にまとめてみた。

鑑別診断として，ムチンを産生する mucoepidermoid carcinoma, 脂質を有する sebaceous carcinoma, ミト コンドリアが豊富な oncocytoma，腎癌・甲状腺癌の転 移が挙げられる.

\section{まとめ}

小唾液腺に発生した EMCの 1 例を経験し，その経過 を報告した。また，本腫瘍に認められる病理組織学的な
特徵を述べると共に，分類上の文献的検討を加えた。

稿を終えるにあたり，ご指導いただいた増田 游教授(岡山 大学医学部耳鼻咽喉科学教室)に感謝致します。

\section{参考文献}

1 ) Seifert G and Sobin LH : Histological Typing of Salivary Gland Tumours. 2nd ed. pp 23 24, Springer-Verlag, Berlin • Heidelberg • New York • London • Paris • Tokyo • Hong Kong $\cdot$ Barcelona $\cdot$ Budapest, 1991.

2 ) Batsakis JG, El-Nagger AD and Luna MA : Pathology consultation epithelial-myoepithelial carcinoma of salivary glands. Ann Otol Rhinol Laryngol 101 : 540 542, 1992.

3 ) Chen KTK : Clear cell carcinoma of the salivary gland. Hum Pathol $14:$ 91 93, 1983.

4) 林 雄三, 竹本 剛, 徳岡昭治: 唾液腺の “clear cell tumor” 8 例の形態学的研究. 病理と臨床 $2: 1640 \sim 1650$, 1984.

5 ）桜井一成, 夏見淑子, 堀池周司, 他 : 口底に発生した明細 胞腫の 1 例とその組織化学的および免疫化学的検討. 日口 外誌 $36: 1671 \sim 1679,1990$.

6 ) Ogawa I, Nikai H, Takata T, et al : Clear cell tumors of minor salivary gland origin. Oral Surg Oral Med Oral Pathol 72 : 200 207, 1991.

7 ) 井野素子, 木下卓也, 中川のぶ子, 他: 舌根部 clear cell tumor の 1 例. 耳鼻 $39: 676 \sim 680,1993$.

8 ) Simpson RHW, Sarsfield PTL, Clarke T, et al : Clear cell carcinoma of minor salivary glands. Histopathology 17 : 433 438, 1990.

9 ）下田勝己, 野崎幹弘, 平山 峻, 他 : 頓粘膜を原発とする 稀な clear cell carcinoma の 1 例. 日頭顎顔外誌 8：63, 1992.

10）川上登史, 西岡絵里子, 林一彦: 軟口蓋原発 Glycogenrich clear cell carcinoma の 1 例. 耳喉頭頸 62:875 880, 1990.

11) Simpson RHW, Clarke TJ, Sarsfield PTL, et al : Epithelial-myoepithelial carcinoma of salivary glands. J Clin Pathol 44 : 419 423, 1991.

12）森川智子，小林省二, 荻野哲朗, 他：耳下腺に発生した epithelial-myoepithelial carcinoma の 1 例. 癌の臨床 36 : 2153 2157, 1990.

13）福島邦博, 中井貴世子，小河原利彰, 他：口蓋に発生した 上皮筋上皮癌の 1 例. 耳鼻頭頸 $66: 255 \sim 259,1994$.

14) Morinaga $S$, Hasimoto $S$ and Tezuka $F$ : Epithelialmyoepithelial carcinoma of the parotid gland in a child. Acta Pathologica Japonica 42 : 358 363, 1992.

15) Fonseca $I$ and Soares J : Epithelial-myoepithelial carcinoma of the salivary glands; a study of 22 cases. Vir- 
chows Arch A Pathol Anat 422 : 389 396, 1993.

16）山岸畺弓美, 北村 豊, 岩本 修, 他: 口蓋に発生した明 細胞腺腫の 1 症例. 日口外誌 $38: 1687 \sim 1688,1992$.
原稿受付 : 平成 7 年12月 8 日 原稿採択: 平成 8 年 1 月 17 日 別刷請求先 : 延藤洋子

厂700 岡山市鹿田町2-5-1

岡山大学医学部耳鼻咽喉科学教室 